\title{
Cashless Policy and Financial Performance of Deposit Money Banks in Nigeria
}

\author{
Muotolu, Peace Chikwemma, Nwadialor, E. 0 \\ Department of Accountancy, Chukwuemeka Odumegwu Ojukwu University, \\ Igbariam Campus, Igbariam, Nigeria
}

\begin{abstract}
How to cite this paper: Muotolu, Peace Chikwemma | Nwadialor, E. O "Cashless Policy and Financial Performance of Deposit Money Banks in Nigeria" Published in International Journal of Trend in Scientific Research and Development (ijtsrd), ISSN: 24566470, Volume-3 | Issue-4, June 2019, pp.465-476, URL: https://www.ijtsrd.c om/papers/ijtsrd23 835.pdf

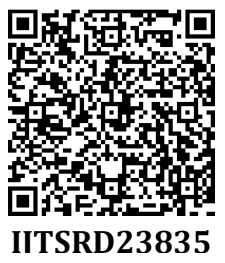

Copyright (C) 2019 by author(s) and International Journal of Trend in Scientific Research and Development Journal. This is an Open Access article distributed under the terms of the Creative Commons

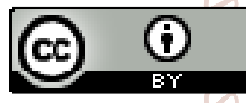
Attribution License (CC BY 4.0) (http://creativecommons.org/licenses/ by/4.0)
ABSTRACT

The study investigated the effect of Central Bank of Nigeria Cash less Policy and the Financial Performance of Deposit Money Banks in Nigeria. A panel data were collected from a sample of 14 banks covering 6 years spanning from 2012 when the policy was introduced in Nigeria to 2017. The study used return on Asset as proxy for bank performance while the value transactions done through the ATM, POS, Internet Banking, NIP and NEFT platforms (E-banking Products) were used to proxy cash less policy. In other to ensure the validity and the reliability of our data, we therefore subjected our data to a diagnostic test using Descriptive Statistic Analysis, Multicolinearity test, Correlation testing, and Herteroskadaticity testing. Findings from the study revealed that that (ATMV) has a positive and significant effect on return on assets (ROA) of banks in Nigeria while, POSV, WEBV, NIPV and NEFV were found to have a positive but insignificant effect on ROA of quoted banks in Nigeria. The study concluded that E-banking products as a proxy for cash less policy has positive effect on the financial performance of Deposit Money Banks in Nigeria. It was thus recommended among others that bank management should pay more attention on the activities that will improve the ATM services if they wish to increase the ROA.

of Trend in Scientific o

\section{INTRODUCTION}

Monetary policy is the process by which the monetary authority of a country, typically the central bank or currency board, controls either the cost of very short-term borrowing or the monetary base, often targeting an inflatio or interest rate to ensure price stability and general trust in the currency. The conduct of monetary policy by the Central Bank of Nigeria since 2008 has been designed to: influence the growth of money supply consistent with the required aggregate Gross Domestic Product (GDP) growth rate, ensure financial stability, maintain a stable and competitive exchange rate of the naira, and achieve positive real interest rates. A nation should encourage a payment system that is safe, suitable and reasonable in order to encourage economic development (Ajayi \& Ojo, 2006). According to a presentation by Banking and Payment System Department of Central Bank of Nigeria in July 2015, Nigeria has been lagging behind in the adoption of e-payment unlike many developed nations like Denmark, Norway, Sweden, UK, USA, France, Switzerland, Philippines, and the likes.

The payments system plays a very crucial role in any economy, being the channel through which financial resources flow from one segment of the economy to the other. It, therefore, represents the major foundation of the modern market economy. Essentially, there are three pivotal roles in the payments system, namely: the monetary policy role, the financial stability role and the overall economic role (CBN, 2015). To further improve the efficiency of the payment system, the CBN in 2004 issued the broad guidelines on electronic banking (e-banking). E-banking practice in Nigeria will continue to be promoted in line with global trend.

The Central Bank of Nigeria, as part of their ambition to be one of the best 20 economies before the year 2020, informed the world that Nigeria would commence the process of changing to a cashless economy by January 2012. "Cash Less Policy" was introduced by CBN to reduce (and not Eliminate) the amount of physical cash (notes and coins) circulating in the economy thereby encouraging the use of electronicbased platforms for settlement or payment for goods and services. The objectives of Cash Less Policy are: to drive development and modernization of our payment systems in line with vision 2020, to reduce cost of banking services, corruption, high cost of cash processing, cash-related crimes and activities of the informal economy, to drive Financial inclusion (Bringing in the unbanked into the financial system), to improve effectiveness of Monetary Policy and to properly allocate cost of processing cash to heavy cash users. The Policy content is as follows: Maximum daily cash withdrawals of N500,000 for Individual account holders; Maximum daily cash withdrawals of N3,000,000.00 for Corporate account holders; Banks are not allowed to offer Cash-in-Transit (CIT) services to their customers. This service is solely domiciled with licensed CIT companies such as Bankers' Warehouse etc. Third party cheques above 
N150,000 cannot be cashed across the counter, they must be presented through the clearinghouse or account to account Transfer; The limits of N500,000 and N3M for Individuals and Corporates respectively are cumulative and include ATM withdrawals; The limit applies to all accounts own by same customer. The penalties of for non-compliance are as follows: $3 \%$ on amounts withdrawn in excess of the set limit of N500,000 for Individual accounts (E.g. a withdrawal of $\mathrm{N} 600,000$ will attract $3 \%$ charge on $\mathrm{N} 100,000$ which translates to $\mathrm{N} 3,000) ; 5 \%$ on amounts withdrawn in excess of the set limit of N3M for Corporate accounts (e.g. a withdrawal of N3.5M will attract $5 \%$ penalty on the excess of N500,000 which translates to N25,000) ; CBN to sanction banks that do not apply penalty on excess withdrawal ; CBN to sanction banks that violate the CIT directive; Charges shall apply on transactions done across the 36 states and FCT from July 1, 2014. The mode of operation of the policy is: Lagos state was used for the pilot phase which started on January 1, 2012. The policy was extended to Abia, Anambra, Kano, Ogun, Rivers and FCT in July 1, 2013. CIT services ceased from January 1, 2012. Nationwide take-off in remaining 30 states from July 1, 2014 and the policy applies to only Naira transactions. Foreign Currencies are exempted. The exemptions from the policy are: Microfinance Banks and PMIs are exempted; Ministries, Departments and Agencies (MDAs); Embassies, Diplomatic Missions and Multilateral and Aid Donor Agencies in Nigeria. The expected benefits of the policy are: Convenience and ease of payment for goods and services, reduced risk of cash related crimes, Cheaper cost of banking services and easy access to credits and Increased economic development, tax collection and greater financial inclusion.

The upsurge in Information Communication Technology (ICT) is what has made cashless banking both possible and meaningful globally. Cashless banking introduction in Nigeria has brought about changes in the banking patterns of the government, organizations, and individuals. It has thrown up so many challenges to all the parties too. Therefore, this study dissects the impact of E-banking products on the financial performances of the Deposit Money Banks in Nigeria.

\section{Statement of the Problem}

The introduction of the cashless policy by the Apex bank, Central Bank of Nigeria brought e-products like the use of Automated Teller Machines (ATM), Point of Sales (POS), mobile banking, internet banking, Nibbs Electronic Funds Transfer (NEFT), Nibbs Instant Payment (NIP) transfers, and others to the fore. This became possible as a result of the rise in ICT globally. The deposit money banks invested a lot in ICT in order to face the challenges posed by cashless policy so as to remain relevant and competitive.

Prior studies like Umanhonlen, Umanhonlen and Igbinoba (2015), Osazevbaru, Sakpaide, and Ibubune (2014), Taiwo, Ayo , Afieroho and Agwu (2017), Achor (2013), Okoye and Ezejiofor (2013), Tunmibi and Falayi (2013), Ajayi (2014), Omotunde , Sunday and John-Dewole (2013) and EzuworeObodoekwe, Eyisi , Emengini and Alio (2014) focused on the prospects, challenges, and benefits of the policy, concentrating on whether the policy has achieved the stated objectives actually outlined by the CBN at the time of introducing the policy. Alagh and Ene (2014), Shehu, Aliyu and Musa (2013), Oladejo ((2016), Ngango (2015), Obiekwe and Anyanwaokoro (2017) actually used the e-banking products to proxy cashless banking and found that they are positively related to the performance of banks. Abaenewe, Ogbulu, and Ndugbu (2013) found that the adoption of electronic banking has positively and significantly improved the returns on equity (ROE) of Nigerian banks. On the other hand and on the contrary, it also revealed that e-banking has not significantly improved the returns on assets (ROA) of Nigerian banks.

Therefore, the result of prior research revealed conflicting results and none of the studies used more than three variables to proxy cashless banking. This study fills the existing gap by introducing two additional variables, NEFT Transfers, and NIP transfers. The study aims at investigating the impact of ATM transactions, POS transactions, Internet banking transaction, NEFT transactions and NIP transaction of the performance of Deposit Money Banks in Nigeria from the inception of the policy in 2012 to 2017.

\section{Objectives of the Study}

The main objective of this study is to ascertain the effect of the Central Bank of Nigeria Cashless Policy on the Performance of Deposit Money Banks in Nigeria. The specific objectives are to:

1. Determine the effect of ATM transactions on the return on asset of Deposit Money Banks in Nigeria.

2. Investigate the extent to which POS transactions enhance the return on asset of Deposit Money Banks in Nigeria.

3. Ascertain the degree to which Internet banking transaction influences the return on asset of Deposit Money Banks in Nigeria.

4. Determine how NEFT Transfers improves the return on asset of Deposit Money Banks in Nigeria.

5. Examine the extent to which NIP transaction affect the Return of assets Deposit Money Banks in Nigeria.

\section{CONCEPTUAL FRAMEWORK}

\section{Performance (Return on Asset)}

Performance is the dependent variable in this research and it is proxied by return on Assets (ROA). Performance can be described as a measure of how well a firm can use assets from its primary mode of business to generate revenues. It shows how efficient the management of an organization uses the assets at its disposal to generate profit. Performance of a business can be measured using different proxies. Abaenewe, Ogbulu, and Ndugbu (2002) proxied performance using return on asset (ROA) and return on equity (ROE). However, it is pertinent to note that firms' profitability is not the only performance measure of an organization. Ibukunle and James (2012), Olorunsegun (2010) and some other researchers have measured performance in a different perspective like productivity, increase in sales, cost reduction, competitiveness, efficiency, and effectiveness. This study, therefore, measures banks' performance using return on assets (ROA) which is consistent with that of Abaenewe et al (2013).

Emekekwue (2008) sees the return on assets (ROA) as a ratio that seeks to measure the amount of profit made from the entire assets of the firm. It is expressed as Profit before tax Total Assets. Ekwe and Duru (2012) opines that return on assets (ROA) was used as dependent variables because it is an indicator of managerial efficacy. Return on assets (ROA) is a dependent variable. It is the quotient of dividing profit after tax by total assets. Lazaridis and Trynidis (2006), 
Falope and Ajilore (2009), Singh and Pandy (2008) and Karaduman et al (2011) agrees that the formula for return on Assets (ROA) is express as Profit before tax over Total Assets.

\section{Automated Teller Machine (ATM)}

This is an automated teller machine that dispenses cash and basically performs all other functions done by a teller in a banking hall like balance inquiry, give mini statements and bills payment, recharge functions etc. A personal identification number (PIN) has to be entered along with credit or debit card to access cash. Some ATMs will allow for cash deposits and bill payments. The CBN has approved N55 as income to the bank from the 4th transaction done by the cardholder of another bank's card on the ATM terminal. It is a cash point that can be used to withdraw cash or do Transfers. A debit card or credit card is used at the machine to withdraw cash. The CBN has stipulated 72 hours for responding to ATM complaints by banks, failing which the customer can escalate to the CBN. The CBN is also trying to establish a card arbitration panel that will act as a payments system ombudsman to fast track resolution of disputes. We should also note that card fraud particularly at the ATM have reduced drastically with the migration of cards to adopt the chip + PIN technology.

\section{Point of Sale (POS) Machine}

Point of Sales (POS) machine or terminal is an electronic device used in payment for goods and services. You find it in supermarkets, hotels, filling stations, shops etc. A charge known as Merchant Service Charge (MSC) is charged on all transactions done on POS terminals, this charge is borne by the merchant. The maximum total fee a merchant can be charged for any POS terminal transaction is $0.75 \%$ of the transaction value or N1,200.00 cap. Point of Sale refers to the location at which a payment of a card transaction occurs, usually by way of a device such as a credit card terminal or cash register. The industry has endorsed four manufacturers for the supply of Point-of-Sale terminals - PAX, Bitel, Ingenico, and Verifone - with negotiated discounts and local support arrangements. A POS can be purchased from any of these four for as low as N45,000.00 per terminal. However, parties are free to purchase POS terminals from any manufacturer; so far they meet the POS specifications in the Point-of-Sale guidelines.

\section{Internet Banking}

It is an electronic payment system that enables customers of a bank or other financial institution to conduct a range of financial transactions through the financial institution's website via electronic devices like mobile phones, Ipads, laptops, Desktops e.t.c right at the comfort of their homes, offices and other places of convenience. In Siyanbola, (2013) internet banking, like uses the electronic card infrastructure for executing payment instructions and final settlement of goods and services over the internet between the merchant and the customers). Internet banking gives customers the opportunity of enjoying banking services from the comfort of their homes and offices. This means that customers can buy goods by placing orders from the net, instruct their banks to pay the vendor the invoice amount involved, and the products are delivered to the destination where the buyer wants.

Nibss Electronic Funds Transfer (NEFT)The NIBSS Electronic Fund Transfer (NEFT) is an irrevocable electronic fund transfer instruction for payment to a 3rd party bank. It was introduced in Nigeria in 2004. NEFT is usually used for high volume payments such as salaries, vendor payments, etc. and are processed via scheduled batch clearing sessions on NIBSS ACH. NEFT transactions are not real-time but beneficiaries receive same day value for transactions posted before the clearing sessions. NEFT payments are implemented in 2 clearing cycles:

1. Same day settlement for the transaction received before clearing sessions.

2. Next day settlement for the transaction received after clearing cycle.You can transfer funds through NEFT by first logging into your bank's internet banking platform using your ID and password. Then you go to fund transfer tab and select add beneficiary (receiver's bank). Select beneficiary type for example transfer to other bank then enter the account number of the beneficiary. Click on send. The bank will first debit your account to ensure that the funds are set aside. Then your instruction (along with other customers' instructions) are sent to NIBSS by your bank as an electronic file for onward processing.

\section{NIBSS Instant Payment (NIP)}

NIP was introduced in 2011 as a real-time interbank payment service predominantly used for single payment transactions (low volume). This service is offered across major banking channels in Nigeria including branch, internet, and mobile banking. For NIP, if you are using your personal computer log into your bank's internet banking platform. Click account transfer tab to expand it. Click on transfer to other bank (instant). If you are using mobile money android application, select NIP. If you are using it for the first time activate it with your token. Then click new request. Select add new beneficiary to add the receiver's bank account details. Fill all required details and enter the code from your token device. Then send. Transfer to other banks will incur charges. The options of NEFT and NIP are also provided in the funds transfer forms in the banks. Hence you can perform any of the two by visiting your bank and complete the funds transfer, indicating NEFT or NIP as your Preferred transfer type.

\section{THEORETICAL FRAMEWORK}

The research is anchored on the Bank focused theory, though two other relevant theories are explained. The Bank focused theory is a theory of branchless banking. It is used here because of the concept of electronic payment anchors on branchless banking.

\section{Bank Focused Theory}

This theory was propounded by Kapoor (2010) and anchors on the ground that banks use non-traditional but conventionallow-cost delivery channels to provide services to its numerous customers. Such channels include the automated teller machines (ATMs), Internet banking, Point of Sale (POS) among others. By making use of these channels, the bank offers a wide range of services to its customers not minding the location and branch where the customer is. The only thing required is to input the needed information into the system and the transaction is concluded. This theory supports this study since the emphasis here is on electronic platforms as a means of delivering services.

\section{Bank-Led Theory}

The bank-led theory of branchless banking was proposed by Lyman, Ivatury, and Stachen (2006) and emphasizes the role 
of an agent who acts as a mediator between the banks and the customers. In this case, the retail agents have direct interaction with the banks' customers and take up the role expected of the bank by either paying cash or collecting deposits (Owens, 2006). Finally, this agent is expected to transmit all his dealings with the bank's customers to the bank he is representing through electronic means (such as phones, internet, etc).

\section{Non-Bank-Led Theory}

This theory was put forward by Hogan (1991). In this theory, customers do not deal with any bank and they do not maintain any bank account. The customers only deal with is a non-bank firm such as mobile network operator or prepaid card issuer who they exchange their cash with for e-money account. The e-money account is then stored in the server of this non-bank agent. This tends to represent the riskiest platform in the electronic payment methods because of the lack of existing regulatory framework upon which these eagents operate.

\section{EMPIRICAL STUDIES}

Obiekwe and Anyanwaokoro (2017) in their study investigated the effect of Electronic Payment Methods (EPM) on the profitability of commercial banks in Nigeria. In order to achieve the broad objective, the study specifically investigated the effect of Automated Teller Machine (ATM), Point of Sale (POS) and Mobile Payment (MPAY) on the profitability of commercial banks in Nigeria. A total sample of five (5) banks was considered for the period 2009 to 2015 and the study adopted the Panel Least Squares (PLS) estimation technique as the analytical tool. Data were collected from the Central Bank of Nigeria (CBN) Statistical Bulletin and Annual Reports and Statements of Accounts of the five banks used in the study. Findings revealed that Automated Teller Machine (ATM) and Mobile Phone payment have a significant effect on the profitability of commercial banks in Nigeria. However, Point of Sale (POS) has an insignificant effect on commercial banks' profitability in Nigeria.

Ewa and Inah (2016), investigated 'Evaluating Nigeria Cashless Policy Implementation using Simple percentages and Relative Important Index (R.I.I), found using a four-point Likert scale questionnaire administered to six hundred respondents. The results of the study show that the twin policy objectives investigated were partially achieved. Also, the study reveals that social infrastructures in power and telecommunications need improvement and expansion and the need to create more awareness to encourage the unbanked to embrace banking culture.

Umanhonlen, Umanhonlen, and Omoruyi (2015) appraised the impact of e-banking and cashless society in the Nigerian economy. The study explores various aspects of e-banking and cashless economy using the banking sector of the Nigerian economy as a focal point. Specifically, the paper articulates empirical opinions that highlight the possible ways these policy measures have direct links to beneficiaries and the weighted outcomes when divergence is noticed and how to bring back the soundness, sustainable and rebranding policy that ensures economic growth. The paper holds that for a sustainable cashless society to emerge all hands must be on deck; banks should de-emphasize all odds and ensure that efficiencies of e-banking mechanisms are of utmost priority.
Osazevbaru, Sakpaide, and Ibubune (2014) in their study examined the impact of cashless policy on the profitability of Nigerian banks, against the backdrop that these banks in a cash-based economy are known for their huge profits even in the face of the associated high cost of operations. Basically, will banks in the cashless regime still make as many profits as they use to make? To address this, secondary data were collected and analyzed using content analysis comparing profits under the cash-based policy with a cashless regime. The results revealed that cashless economic policy positively impacts on banks' reduction profit in the cost of operations through banking the unbanked populace.

Taiwo, Ayo, Afieroho, and Agwu (2017) in their study appraised the implementation of the cashless policy since its introduction into the Nigerian financial system in 2012 and also to examine the persistent challenges facing its implementation. In view of the above-stated objective, primary data were collected with the aid of the questionnaire, which was randomly administered to 120 respondents ranging from First Bank, Zenith Bank and United Bank for Africa. The banks were selected based on their total assets and the information collected covered the activities of the CBN and that of these banks towards implementation of the cashless policy from 2012 to date. The data collected were presented and analyzed with the aid of the Statistical Package for Social Sciences (SPSS) using descriptive statistics and one-sample t-test. The results led to the conclusion that despite the need to operate cashless transactions dominating the modern Nigerian economy, the cashless policy will have the desired impact only if a lot is done to ensure the implementation of an effective cashless system. fic

Princewell (2013) examined issues in economic policy drift in payment systems with reference to Nigeria's shift from a cash-based economy to a cashless society. Using the survey method, the study sampled 650 stakeholders (respondents) comprising of Businessmen, University Students, and civil servants. Results show that the majority of the stakeholders support the policy. The key reason why they support the policy is that of its potential in reducing cash-related robberies, corruption, and other fraudulent practices among others. On the other hand, stakeholders who are against the policy shift hinged their reasons on payment fraud associated with the cashless economy; high rate of illiteracy and infrastructural decay in Nigeria.

Okoye and Ezejiofor (2013) examined the significant benefits and essential elements, of cashless policy and to check the extent to which it can enhance the growth of financial stability in the country. Two research hypotheses were formulated in line with the objectives of the study. The descriptive research design was adopted for the study with a sample size of 68 . The convenience sampling technique was used. The questionnaire which was structured was the main instrument used for data collection. The data collected was subjected to face validity test, and was tested with ANOVA and chi-square (x2) technique was used to test the hypotheses. The results indicate that: a majority of Nigerians are already aware of the policy and majority agree that the policy will help fight against corruption/money laundering and reduce the risk of carrying cash. Major problems envisaged hampering the implementation of the policy are cyber fraud and illiteracy. 
Tunmibi and Falayi (2013) investigated Information technology security and e-banking in the Nigeria banking industry. A total of forty customers were sampled from nine different banks in Nigeria using accidental sampling method and questionnaire was used as the data collection instrument. Information technology has been acknowledged as the life wire of banks in the financial sector as it promotes and facilitates the performance of banks in various countries. However, with respect to IT security in Nigeria, there is a variation in the level of trust that customers have in their banks. Most of the sampled customers responded that network is unreliable and there is an occasional experience of cash deduction without cash withdrawal when using ATM. They noted that IT security is a major challenge to e-banking in Nigeria and the banking industry is not stable enough for e-banking.

In his study, Adewoye (2013) the impact of mobile banking on service delivery in the Nigeria commercial banks. The study was carried out in Lagos state with One hundred and forty (140) Questionnaires administered and distributed to both senior and junior staff of the selected banks, Thirty-five (35) staff each was picked from the four (4) selected banks. One hundred and Twenty-five (125) Questionnaires were found useful for the purpose of the study representing $83.3 \%$ of the total questionnaire distributed. Data collected was analyzed using frequency table, percentage and mean score analysis while the non-parametric statistical test Chisquare was used to test the formulated hypothesis using STATA 10 data analysis package/software to examine the impact of mobile banking on service delivery and also look at the relationship between mobile banking and service delivery in the sampled banks. The results of the findings show that Mobile banking improved banks service delivery in a form of transactional convenience, savings of time, quick transaction alert and save of service cost which has to recuperate customer's relationship and satisfaction.

Ajayi, (2014) in his study examined the effect of cashless monetary policy on the Nigerian banking industry. Out of 5000 Guaranty Trust Bank (GTBank) staff, 370 sample sizes were selected based on Taro Yemane's formula for sample size. The study was carried out in Ekiti State, Nigeria with 370 questionnaires administered to the bank staff in the state. Of the total questionnaires distributed, 350 questionnaires (representing 95\%) were returned. The data collected were analyzed using frequency table and percentages while for the non-parametric statistical test, Chi-square was used to test the formulated hypothesis. The results of the study showed that there are significant reasons and benefits inherent in the implementation of cashless policy. It also showed that the policy has positively affected the development of banks; as it facilitates ease of operations and reduces queue and congestion in the banking hall, among others.

Omotunde, Sunday and John-Dewole (2013) investigated the impact of cashless policy in Nigeria. Survey research was adopted with the questionnaire as data collection instrument. Responses from the respondents show that cashless policy will increase employment; reduce cash related robbery thereby reducing the risk of carrying cash; cashless policy will also reduce cash related corruption and attract more foreign investors to the country. The study, therefore, shows that the introduction of the cashless economy in Nigeria can be seen as a step in the right direction. It is expected that its impact will be felt in the modernization of Nigeria payment system, reduction in the cost of banking services, reduction in high security and safety risks and also curb banking related corruptions.

Ezuwore-Obodoekwe, Eyisi, Emengini, and Alio (2014) critically analyzed Cashless Banking Policy in Nigeria. Using survey design, they found that Cashless policy has affected deposits taking, cash withdrawals, money transfers, loan administration; the provision of banking services in several ways, these include quick data processing and retrieval of information increased customers' satisfaction, quick customer service delivery and production of accurate and reliable information, faster access to capital, reduced revenue leakage and reduced cash handling costs.

Odior and Banuso (2013) in their study examined the implications of cashless banking, with a view to exposing the possible challenges and prospects it poses to the Nigerian economy whilst employing the aggregated approach. Descriptive statistics were used to highlights/overview of the effectiveness of the cash-less policy of the CBN in Nigeria. This study also seeks to evaluate the policies of the Central Bank of Nigeria as well as proffer valuable recommendations on the execution of the cash less policy. The result showed that cashless banking has the possibility of stimulating trade and commercial activities as the velocity of circulation (rate at which money changes hands) is likely to increase in the long-run.

In 2013, Hassan, Mamman, and Farouk investigated the influence of electronic banking products on the performance of Nigerian DMBs. The study became necessary as a result of increased penetration of electronic banking which has redefined the banking operations in Nigeria and the world over. The population of the study is all the twenty-one Deposit Money Banks (DMBs) listed on the Nigerian Stock Exchange. Systematic sampling technique was used and six (6) banks were selected as the sample of the study. Data were collected from the secondary source through the annual report and accounts of the sampled Banks and insider information from the employees working in the selected banks, respectively. The performance of these banks was measured in terms of returns on equity (ROE) The study revealed that the adoption of electronic banking products (emobile and ATM transactions) has strongly and significantly impacted on the performance of Nigerian banks while on the other hand, it revealed that e-direct and SMS alert have not significantly impacted on the performance of the banks.

Morufu (2016) in their study examined the impact of four (ATM, POS, web/Internet and mobile) e-payments adoption and banks specific variables on the profitability of the Nigerian Deposits Money Banks (DMBs). Secondary data were obtained from the annual report and accounts often quoted (DMBs) between 2005 and 2012. Data were analyzed using panel logistic regression. The overall result from data analysis shows that when bank adopts e-payment systems, their performance level, such as gross margin, profits after tax, return on assets and return on equity changes. This is reflected in the positive association between adoption and gross earning of banks. Further, adoption of the four epayment instruments like ATM, WEB, POS and Mobile banking influenced performance indices measured by return on assets (ROA), gross margin and profits after tax (PAT) of the sampled banks. 
Oyewole, Abba, Gambo and Arikpo (2013) investigated the impact of electronic banking on banks' performance in Nigeria. Panel data comprised annual audited financial statements of eight banks that have adopted and retained their brand name banking between 2000 and 2010 as well as macroeconomic control variables were employed to investigate the impact of e-banking on return on asset (ROA), return on equity (ROE) and net interest margin (NIM). The result from pooled OLS estimations indicate that e-banking begins to contribute positively to bank performance in terms of ROA and NIM with a time lag of two years while a negative impact was observed in the first year of adoption.

Asia (2015) examine the contribution of E-banking towards banking on performance of banking Institutions in Rwanda because according to National bank of Rwanda (NBR Report, 2012) there is delay in payment of checks between banks; time wasted in banks as people line in queue waiting for service, errors as a result of manual work and fraud related cases was common. As a result, some clients complain of the above hence the researcher would like examined the contribution of this system to banking efficiency in Rwanda. The study will be significant to the researcher; Bank of Kigali, Jomo Kenyatta University of Agriculture and Technology and other scholars who have an interest in the same area.

Literature by different scholars was reviewed especially on the contribution of E-banking towards banking on the performance of banking Institutions. The researcher will use the descriptive method of study based on the qualitative and quantitative approach in order to get a better analysis of the study. He will use both primary and secondary data collection tools with their relevant tools like questionnaire and documentary analysis in order to come up with required data. In the findings it was established that Electronic banking system like ATM, Pay direct, electronic check conversion, mobile telephone banking and $\mathrm{E}$ transact has a great impact on bank performance because they increase profitability, reduce bank cost of operations, and increase bank asset and bank efficiency. The great contributions of ebanking on banking performance is shown in Table 4.21 which provides the relationship between E-banking and Performance of Bank of Kigali in Rwanda whereby the respondents, $\mathrm{N}$ is 44 and the significant level is 0.01 , the results indicate that the independent variable has positive high correlation to dependent variable equal to $.656^{* *}$ and the p-value is .000 which is less than 0.01 . When p-value is less than significant level, therefore researchers conclude that variables are correlated and the null hypothesis is rejected and remains with an alternative hypothesis. This means that there is a significant relationship between Ebanking and Performance of Bank of Kigali in Rwanda. As conclusion E-banking contributes to the positive performance of banks as witnessed by Kigali, Afonja, Akande, and Olure-Bank (2015) in their study appraised the implications of cashless banking, with a view to exposing the possible challenges and prospects it poses to the Nigerian economy whilst employing aggregated approach. It specifically sought to find out how cashless policy can mobilize and increase total domestic saving by increasing bank credit of deposit money banks injected into the Nigerian economy, and their impact on the country's economic growth as proxies by Gross Domestic Product. Data were collected from secondary sources. The ordinary least square econometric technique was used to analyze the data. The a priori expectation is that bank credit to the domestic economy should have a significant positive impact on the growth of GDP. Our findings revealed that the marginal productivity coefficient of bank credit to the domestic economy is positive but insignificant.

Ugwueze and Nwezeaku (2016) studied the relationship between electronic banking and the performance of Nigerian commercial banks. The study became necessary due to the increased adoption of electronic banking which has redefined the banking service both in Nigeria and internationally. Electronic banking was proxied by the value of Point-of-Sale transactions while commercial banking performance was proxied by customers' deposits. EngleGranger co-integration model was used to analyze data for the sample period January 2009 to December 2013. The results show that POS is not co-integrated with both the savings and time deposits but are co-integrated with demand deposits.

Abaenewe, Ogbulu, and Ndugbu (2013) investigated the profitability performance of Nigerian banks following the full adoption of the electronic banking system. The study became necessary as a result of increased penetration of electronic banking which has redefined the banking operations in Nigeria and around the world. The judgmental sampling method was adopted by utilizing data collected from four Nigerian banks. These four banks are the only banks in Nigeria that have consistently retained their brand names and remain quoted in the Nigerian Stock Exchange since 1997. The profitability performance of these banks was measured in terms of returns on equity (ROE) and returns on assets (ROA). With the data collected, we tested the preand post-adoption of e-banking performance difference between means using a standard statistical technique for an independent sample at 5 percent level of significance for performance factors such as ROE and ROA. The study revealed that the adoption of electronic banking has positively and significantly improved the returns on equity (ROE) of Nigerian banks. On the other hand, and on the contrary, it also revealed that e-banking has not significantly improved the returns on assets (ROA) of Nigerian banks.

Njogu (2014) in their study examined the effects of electronic banking on the profitability of commercial banks in Kenya. These data were collected from the Central Bank of Kenya and Commercial banks. Regression analysis was done for the period to determine the effects of electronic banking on the profitability of commercial banks in Kenya. The study covered a period of 5 years from the year 2009 to 2013. The findings on the coefficient of determination, the study found that major changes in the financial performance of commercial banks in Kenya could be accounted to changes in internet banking, the point of sales, automatic teller machine, mobile banking and size of the bank at 95\% confidence interval. The study found that there was a strong positive relationship between the financial performance of commercial banks and electronic banking, as it was found that there was a strong relationship between the financial performance of commercial banks and electronic banking. Size of the bank was also found to positively influence the financial performance of commercial banks in Kenya.

\section{Summary of Prior Studies}

Some researchers on the topic like Ewa and Inah (2016), Umanhonlen, Umanhonlen, and Omoruyi (2015), 
Osazevbaru, Sakpaide, and Ibubune (2014), Taiwo, Ayo, Afieroho and Agwu (2017), Achor (2013), Okoye and Ezejiofor (2013) and Tunmibi and Falayi (2013) were merely exploratory, giving the challenges, benefits, whether cashless policy is helping to fight corruption or not, and whether the objectives of policy is being achieved or not. Studies like Obiekwe and Anyanwaokoro (2017) and Ugwueze and Nwezeaku (2016) found POS to be insignificant to performance while Njogu (2014) and Itah and Ene (2014) found POS to be positively significant to performance leading to conflicting results. Most previous research used two or three variables but the researcher introduced two additional variables, NEFT and NIP transfers, thereby covering a gap in the research topic and adding to the existing literature.

\section{METHODOLOGY}

This study used ex-post facto research design to describe the effects of E-banking products on the financial performance of deposit money banks by using existing data from financial statement of the quoted firms which cannot be manipulated. The study covered all listed Deposit Money banks from 2012 to 2017. The period was chosen as the cashless policy took effect in Nigeria in 2012. This study made use of secondary data as the main source of information and was sourced from the annual report and accounts of the banks and data from CBN payment statistics from 2012 to 2017. The data on the e-banking products (ATM transactions, POS transactions. Internet banking transaction, NEFT and NIP transactions) were analyzed using Descriptive Statistic Analysis, Multicollinearity test, Correlation testing, and Herteroskadaticity testing

\section{Operationalization of Variables:}

\begin{tabular}{|c|c|}
\hline Variables (code) & Proxies (operational definitions) \\
\hline Dependent Variable & \\
\hline Return on Assets (ROA) & Profit Before Interest and Tax/Total Assets \\
\hline Independent Variables & \\
\hline ATM Transactions & Volume/Value of ATM transactions \\
\hline POS Transactions & Volume/Value of POS Transactions \\
\hline Internet Transactions & Volume/Value of Internet Transactions \\
\hline NEFT Transactions & Volume/Value of NEFT Transactions \\
\hline NIP Transactions & Volume/Value of NIP Transactions \\
\hline
\end{tabular}

\section{Model Specification}

The linear regression model used in this study is adapted from the prior studies of Shehu et al (2013) and Ogare, (2013) with modification. Consistent with previous studies, this model modified and extended the model tested by prior studies and the ordinary least square was guided by the following linear model

$\mathrm{Y}=\mathrm{F}[\mathrm{X} 1, \mathrm{X} 2, \mathrm{X} 3, \mathrm{X} 4, \mathrm{X} 5]$

Performance $=\int[$ ATM, POS,IB, NFT, NP, $]$

Based on the above model, we specify the following regression equation

$\mathrm{ROA}=\beta 0+\beta 1 \mathrm{ATM}+\beta 2 \mathrm{POS}+\beta 3 \mathrm{IB}+\beta 4 \mathrm{NFT}+\beta 5 \mathrm{NP}+\varepsilon$.

Where ROA denotes the return on assets (the proxy for DBMS Performance)

ATM $=$ Volume of Transactions done through the Automated Teller Machine

POS $=$ Volume of Transactions done through the Point of Sale machine

IB = Volume of Transactions done through the internet

NFT = Volume of Transactions done through the NEFT platform

$\mathrm{NP}=$ Volume of Transactions done through the NIP platform

$\varepsilon$ is the error term of the model and $\beta 0, \beta 1, \beta 2, \beta 3, \beta 4, \beta 5 \ldots . . .=$ Regression model coefficients.

\section{DATA PRESENTATION AND ANALYSIS}

Table 1: descriptive statistics

\begin{tabular}{|c|c|c|c|c|c|c|c|}
\hline & ROA & ATMV & POSV & WEBV & NIPV & NEFV & FSIZE \\
\hline Mean & 1.68 & 3981.67 & 523.17 & 93.67 & 25763.50 & 14200.33 & 21.06 \\
\hline Median & 1.63 & 3825.00 & 380.50 & 83.00 & 22785.00 & 14446.00 & 20.98 \\
\hline Maximum & 5.09 & 6438.00 & 1410.00 & 185.00 & 56166.00 & 14946.00 & 22.45 \\
\hline Minimum & -5.59 & 1985.00 & 48.00 & 32.00 & 3891.00 & 13087.00 & 19.310 \\
\hline Std. Dev. & 1.65 & 1449.29 & 459.02 & 52.24 & 17481.75 & 638.96 & 0.75 \\
\hline Skewness & -0.98 & 0.35 & 0.96 & 0.56 & 0.51 & -0.65 & -0.20 \\
\hline Kurtosis & 7.32 & 2.13 & 2.66 & 2.09 & 2.11 & 2.03 & 2.42 \\
\hline Jarque-Bera & 78.74 & 4.38 & 13.25 & 7.38 & 6.36 & 9.12 & 1.75 \\
\hline Probability & 0.00 & 0.11 & 0.00 & 0.03 & 0.04 & 0.01 & 0.42 \\
\hline Observations & 84 & 84 & 84 & 84 & 84 & 84 & 84 \\
\hline
\end{tabular}

significance, ${ }^{* * *} 10 \%$ level of significance. 
From Table 1 the mean (average), maximum values, minimum values, standard deviation and Jarque-Bera (JB) Statistics (normality test) were shown. The results expressed in Table 1 helps to provide some insight into the nature of the selected quoted manufacturing firms in Nigerian used in this study. First, it can be observed that on the average, in a 6-year period (2012-2017), the sampled deposit money banks used for this study were characterized by positive ROA $=1.599383$. This is an indication that most quoted banks in Nigeria have a positive Return on Assets (ROA). Similarly, the table also shows that on the average during the period under study that volume of transaction for ATMV was 3981.667, the maximum value stood at 6438.000 while the minimum value stood at 1985.000 , thus showing a large difference between the minimum and maximum values of the ATMV transaction volume, meaning that large number of Nigeria bank customers are using more ATM facilities in most of their transactions that involves cash transactions. This result therefore justify the need for this study as we expect those banks that are recorded high ATM transactions to perform better than those with less ATM transactions, in terms of ROA of such banks.

Furthermore, the table also shows that on the average during the period covered by this study, that volume of transaction for POSV was 523.1667, the maximum value stood at 1410.000 while the minimum value stood at 48.000 thus showing a large difference between the minimum and maximum values of the POSV transaction volume, meaning that large number of Nigeria bank customers have adopted the use of POS facilities in most of their transactions that involves cash. This result therefore justifies the need for this study as we expect those banks that recorded high POS transactions to perform better than those with less POS transactions, in terms of ROA of such banks in Nigeria.

In addition, the table also shows that on the average during the period under study that volume of transaction for WEBV was 93.66667, the maximum value stood at 185.0000 while the minimum value stood at 32.0000 , thus showing a large difference between the minimum and maximum values of the ATMV transaction volume, meaning that large number of Nigeria bank customers are using also WEBV facilities in most of their transactions that involves cash transactions. This result therefore justify the need for this study as we expect those banks that are recorded high WEBV transactions to perform better than those with less WEBV transactions, in terms of ROA of such banks.

Again, the table also shows that on the average during the period under study that volume of transaction for NIPV was 25763.5 , the maximum value stood at 56166.00 while the minimum value stood at 3891.000 , thus showing a large difference between the minimum and maximum values of the NIPV transaction volume, meaning that large number of Nigeria bank customers are using more NIP facilities in most of their transactions that involves cash transactions. This result therefore justify the need for this study as we expect those banks that are recorded high NIP transactions to perform better than those with less NIP transactions, in terms of ROA of such banks

Also, the table also shows that on the average during the period under study that volume of transaction for NEFV was 14200.00 , the maximum value stood at 14946.00 while the minimum value stood at 13087.00 , thus showing a large difference between the minimum and maximum values of the NEFV transaction volume, meaning that large number of Nigeria bank customers are using more NEFV facilities in most of their transactions that involves cash transactions. This result therefore justify the need for this study as we expect those banks that are recorded high NEFV transactions to perform better than those with less NEF transactions, in terms of ROA of such banks.

The table also shows that firm size (FSIZE) showed that the sampled banks used for this study are not mainly dominated by either large or small banks and are widely dispersed. This is confirmed by the wide variations recorded in the standard deviation values of the FSIZE variables used. Lastly, in table 1 , the Jarque-Bera (JB) which test for normality or the existence of outliers or extreme values among the variables shows that most of the variables are distributed normally at the $1 \%$ level of significance except WEBV,NIPV and ATMV that were normally distributed at 5 and $10 \%$ level of significance respectively. This implies that any variable with outlier are not likely to distort our conclusion and are therefore reliable for drawing generalization. This also implies that the least square estimation can be used to estimate the pooled regression model.

\section{Diagnostic Test to Check for Multicolinearity Problem, Using Correlation Metrix.}

Multicolinearity is a near perfect, a high correlation between any two (2) independent variables. It is a problem of crosssectional data and our data have cross sectional characteristics as it cut across fourteen (14) deposit money banks in Nigeria. When there is multicolinearity, all your tvalues, $\mathrm{F}$-statistics value becomes invalid and the $\mathrm{R}^{2}$ of the regression result becomes unreliable. The study on trying to diagnose for the presence of multicolinearity in our data used, as well as evaluating the association among the variables adopted, employed the Pearson correlation coefficient (correlation matrix) analysis. The result obtained is presented in Table 2 .

TABLE 4.2: Pearson Correlation Matrix

\begin{tabular}{cccccccc} 
& \multicolumn{8}{c}{ coa } & atmv & posv & webv & nipv & nefv & fsize \\
roa & 1.0000 & & & & & & \\
atmv & -0.0386 & 1.0000 & & & & & \\
posv & -0.0264 & 0.9739 & 1.0000 & & & & \\
webv & -0.0353 & 0.9926 & 0.9880 & 1.0000 & & & \\
nipv & -0.0380 & 0.9966 & 0.9855 & 0.9991 & 1.0000 & & \\
nefv & 0.0732 & 0.5343 & 0.5308 & 0.5042 & 0.5084 & 1.0000 & \\
fsize & 0.4154 & 0.2762 & 0.2640 & 0.2717 & 0.2735 & 0.1502 & 1.0000
\end{tabular}


The use of correlation matrix in most regression analysis is to check for multicolinearity and to explore the association between each explanatory variable (ATMV, POSV, WEBV, NIPV, NEFVand FSIZE ) and the dependent variable (ROA). Table 2 focused on the correlation between Return on Assets measured as ROA and the independent variables (ATMV, POSV, WEBV, NIPV, NEFV and FSIZE ). The finding from the correlation matrix table shows that most of our independent variables, (ATMV = -0.0386; POSV = -0.0264; WEBV $=-0.0353, \mathrm{NIPV}=-0.0380$, and FSIZE $=-0.1157$ ) were observed to be negatively and weakly associated with Return on Assets (ROA) while NEFV $=0.0732$, FSIZE $=0.4152$ were found to be positively associated with ROA. In checking for multicolinearity, we notice that some of our explanatory variables were perfectly correlated (POSV, ATMV=0.9739; WEBV, ATMV=0.9926; WEBV, POSV=0.9880; NIPV, ATMV=0.9966; NIPV, POSV=0.9855; NIPV, WEBV=0.9991). This means that there is problem of multicolinearity between the explanatory variables. Multicollinearity usually results to wrong signs or implausible magnitudes in the estimated model coefficients obtained. There will also be bias in the standard errors of the coefficients. To further check for the presence of multicolinearity problem in our model, the Variance Inflation Factor (VIF) test was used. The results of this test are presented in table3.

Table 3: VIF test for Multicolinearity in Regression

\begin{tabular}{|c|c|}
\multicolumn{2}{|c}{ Model } \\
\hline Explanatory variable & VIF \\
\hline ATMV & 10190.23 \\
\hline POSV & 316.74 \\
\hline WEBV & 19886.75 \\
\hline NIPV & 64643.41 \\
\hline NEFV & 15.31 \\
\hline FSIZE & 1.09 \\
\hline MEAN VIF & 13579.22 \\
\hline
\end{tabular}

Table 5: ROA Pooled Ordinary Least Square (OLS) Regression Result

Dependent Variable: ROA

Method: Panel Least Squares

Sample: 20122017

Periods included: 6

Cross-sections included: 14

Total panel (balanced) observations: 84

\begin{tabular}{|c|c|c|c|c|}
\hline Variable & Coefficient & Std. Error & t-Statistic & Prob. \\
\hline C & -40.57734 & 16.90403 & -2.400454 & 0.0188 \\
\hline ATMV & 0.012565 & 0.011904 & 1.055506 & 0.0945 \\
\hline POSV & 0.006904 & 0.006591 & 1.047575 & 0.2982 \\
\hline WEBV & 0.557556 & 0.464165 & 1.201202 & 0.2334 \\
\hline NIPV & -0.002875 & 0.002494 & -1.152843 & 0.2526 \\
\hline NEFV & -0.000673 & 0.001022 & -0.657914 & 0.5126 \\
\hline FSIZE & 0.972391 & 0.229492 & 4.237138 & 0.0001 \\
\hline R-squared & 0.238073 & Mean dependent var & 1.682143 \\
\hline Adjusted R-squared & 0.167896 & \multicolumn{5}{|c|}{ S.D. dependent var } & 1.649000 \\
\hline S.E. of regression & 1.504214 & Akaike info criterion & 3.744810 \\
\hline Sum squared resid & 171.9620 & \multicolumn{5}{|c|}{ Schwarz criterion } & 3.976317 \\
\hline Log likelihood & -149.2820 & Hannan-Quinn criter. & 3.837874 \\
\hline F-statistic & 3.392442 & \multicolumn{5}{|c}{ Durbin-Watson stat } & 1.546802 \\
\hline Prob(F-statistic) & 0.003321 & \multicolumn{5}{l}{} \\
\hline
\end{tabular}

In table 5, R-squared and its adjusted R-squared values were (0.238073) and (0.167896) respectively. This is an indication that all the independent variables jointly explain about $24 \%$ of the systematic variations in Return on Assets (ROA) of our sampled quoted banks over the six-year period (2012-2017) while $86 \%$ of the systematic variations are captured by the error term. The F-statistics of 3.392442 and its P-value of $(0.00)$ portrays that fact that the ROA regression model is well specified. In addition to the above, the specific findings from each explanatory variable are provided as follows:
The VIF for each of the explanatory variables was much greater than the threshold of 10 and the overall VIF mean value was more than 5 . Another major regression estimation problem is the existence of heteroskedaticity (i.e. nonconstant residual term) which is often common with crosssectional data. The existence of this problem may result in this problem, the Breush-Pagan-Godfrey heteroskedaticity

Table4: Breusch-Pagan-Godfrey Heteroskedaticity Test

\begin{tabular}{|c|c|c|}
\hline Test & Values & P-values \\
\hline F-Statistics & 3.16 & 0.0757 \\
\hline Obs*R-squared & 5.22 & 0.64 \\
\hline
\end{tabular}

The F- Statistics and Obs* R-squared values of 3.16 and 5.22 respectively shows that there is the absence of heteroskedaticity problem in our model. The P-value $10 \%$ level also confirms that we should accept HO (Absence of heteroskedaticity) and reject $\mathrm{H} 1$ (Presence of heteroskadeticity.

\section{MODEL 1}

$\mathrm{ROA}=\beta 0+\beta 1 \mathrm{ATMV}+\beta 2 \mathrm{POSV}+\beta 3 \mathrm{WEBV}+\beta 4 \mathrm{NIPV}+\beta 5$ $\mathrm{NEFV}+\beta 6 \mathrm{FSIZE}+\mathrm{Er}$

Testing of Hypotheses Formulated for Quoted Deposit Money Banks in Nigeria

In other to examine the impact relationships between the dependent variable ROA and the independent variables (ATMV, POSV, WEBV, NIPV, NEFV and FSIZE) and to also test the formulated hypotheses given, the study used a pooled multiple regression analysis, owing to the fact that the data had both time series (2012-2017) and cross sectional properties (14 quoted Deposit Money Banks in Nigeria). The result of the regression analysis is presented in is presented as table 5 and is interpreted below. wrong t-values and f-statistics. To test for the existence of 


\section{Test of Hypothesis One}

Automated Teller Machine(ATMV), based on the t-value of 1.055506 and P-value of 0.09 , in table 5 was found to have a positive influence on our sampled quoted deposit money bank's (ROA) and this influence is statistically significant at $10 \%$ level of significance as the P-value is within $10 \%$ significance level. This result, therefore suggests that we should reject our null hypothesis one $\left(\mathrm{HO}_{1}\right)$ which states that ATM transactions have no significant effect on return of assets (ROA) of deposit money banks in Nigeria. This means that in Nigeria, there is a high level usage of ATM machines by customers of the sampled banks in Nigeria and this high usage level of bank's ATM machine influences the ROA of the sampled banks positively, thus, leading to the banks better performance. Therefore, as this influence is statistically significant, management should pay more attention on the activities that will improve the ATM services of their banks if they wish to increase the ROA value of their banks as this will lead to high customer's satisfaction and patronage as the study discovers that such efficient ATM services will influence their ROA positively. Therefore on the basis of efficient use of ATM transactions to generate increased ROA, those firms that embark on more activities that improves their ATM services performance better than those with less ATM transactions in Nigeria.

\section{Test of Hypothesis Two}

POSV, based on the t-value of 1.047575 and P-value of 0.30 , in table 5 was found to have a positive influence on our sampled quoted deposit money bank's (ROA) and this influence is not statistically significant since the P-value is more than $10 \%$ significance level. This result, therefore suggests that we should accept our null hypothesis two $\left(\mathrm{HO}_{2}\right)$ which states that there is no significant influence of POS transactions on return of assets(ROA) of deposit money banks in Nigeria. This means that in Nigeria, there is a high level usage of POS machines by customers of the sampled banks in Nigeria and this high usage level of bank's POS machine influences the ROA of the sampled banks positively, thus, leading to the banks better performance but this influence is not statistically significant and therefore, should be ignored by managements when planning to improving their ROA value through POS transactions.

\section{Test of Hypothesis Three}

Internet banking (WEBV), based on the t-value of 1201202 and P-value of 0.23 , in table 5 was found to have a positive influence on our sampled quoted deposit money bank's (ROA) and this influence is not statistically significant since the P-value is more than $10 \%$ significance level. This result, therefore suggests that we should accept our null hypothesis three $\left(\mathrm{HO}_{3}\right)$ which states that internet banking transactions has no significant influence on return of assets (ROA) of deposit money banks in Nigeria. This means that in Nigeria, there is a high level usage of internet banking (WEBV) machines by customers of the sampled banks in Nigeria and this high usage level of bank's WEBV transactions influences the ROA of the sampled banks positively, thus, leading to the banks better performance but this influence is not statistically significant and therefore, should be ignored by managements when planning to improving their ROA value through internet banking (WEBV) transactions.

\section{Test of Hypothesis Four}

NIPV, based on the t-value of -1.52843 and P-value of 0.25 , in table 5 was found to have a negative influence on our sampled quoted deposit money bank's (ROA) and this influence is not statistically significant since the P-value is more than $10 \%$ significance level. This result, therefore suggests that we should accept our null hypothesis four $\left(\mathrm{HO}_{4}\right)$ which states that NIPV transactions have no significant reactions on return of assets (ROA) of deposit money banks in Nigeria. This means that in Nigeria, there is a high level usage of NIPV services by customers of the sampled banks in Nigeria and this high usage level of bank's NIPV machine influences the ROA of the sampled banks positively, thus, leading to the banks better performance but this influence is not statistically significant and therefore, should be ignored by managements when planning to improving their ROA value through NIPV transactions.

\section{Test of Hypothesis Five}

NEFV, based on the t-value of -0.657914 and P-value of 0.51 , in table 5 was found to have a negative influence on our sampled quoted deposit money bank's (ROA) and this influence is not statistically significant since the P-value is more than $10 \%$ significance level. This result, therefore suggests that we should accept our null hypothesis five $\left(\mathrm{H}_{5}\right)$ which states that NEFV transactions have no significant improvement on return of assets (ROA) of deposit money banks in Nigeria. This means that in Nigeria, there is a high level usage of NEFV services by customers of the sampled banks in Nigeria and this high usage level of bank's NIPV machine influences the ROA of the sampled banks positively, thus, leading to the banks better performance but this influence is not statistically significant and therefore, should be ignored by managements when planning to improving their ROA value through NEFV transactions.

\section{Test of Control Variable (Firm size)}

Firm size(FSIZE), based on the t-value of 4.237138 and Pvalue of 0.00 , in table 5 was found to have a positive influence on our sampled quoted deposit money bank's (ROA) and this influence is statistically significant at $1 \%$ level since the P-value is less than 1 significance level. This result, therefore suggests that we should reject our null hypothesis six $\left(\mathrm{HO}_{6}\right)$ which states that firm size (FSIZE) does not significantly affect return of assets (ROA) of deposit money banks in Nigeria. This means that in Nigeria, large sized firms significantly perform better than small sized firms in terms of their ROA performance. Therefore on the basis of efficient use of firm size(FSIZE) transactions to generate increased ROA, those firms with large firm sizes performance better than those with less firm sizes in Nigeria and since this effect is statistically significant. Management should consider improving their firm sizes as this will increase their ROA significantly positive.

\section{Discussion of Results}

This study investigated the effect of CBN cashless policy on return of assets (ROA) of deposit money banks in Nigeria. Using pooled data, the data generated were subjected to different statistical tests such as descriptive statistics, correlation analysis multicolinearity test, heteroskedaticity test and Ordinary Least Square regression analysis. The descriptive statistics revealed the individual characteristics of the variables used in this study which also revealed that the variables were normally distributed.

The regression result shows that (ATMV) has a positive and significant effect on return on assets (ROA) of banks in Nigeria. This finding supports our prior expectation as we 
expect that the use of ATM will lead high performance of ROA of banks in Nigeria. This our findings agrees with the findings of Obiekwe and Anyanwaokoro (2017) and did not negates the findings of Oyewole, Abba, El-maude, Gambo and Abam (2013) out rightly but that the positive performance is noticed after two years. Secondly, the regression results also show that POSV, WEBV, NIPV, and NEFV all were found to have a positive but insignificant effect on ROA of quoted banks in Nigeria. Theses finding do not support our prior expectation and also agrees with the findings of Abaenewe, Ogbulu, Onyemachi and Ndugbu (2013) and negates the findings of Alagh and Ene (2014). In other words, CBN cash less policy does not significantly affect return on assets (ROA) except ATMV, even though they all have positive effects on ROA of banks in Nigeria.

\section{CONCLUSION AND RECOMMENDATION}

This study investigated the effect of CBN cashless policy on return of assets (ROA) of deposit money banks in Nigeria. The study attempted to provide empirical evidence of the effects of the E-banking products (ATMV, POSV, WEBV, NIPV and NEFTV) on the financial performance of deposit money banks in Nigeria. Findings from the study revealed that that (ATMV) has a positive and significant effect on return on assets (ROA) of banks in Nigeria. On the other hand, POSV, WEBV, NIPV and NEFV all were found to have a positive but insignificant effect on ROA of quoted banks in Nigeria. On the basis of the findings and conclusions of the study the paper recommends among others that:

1. Management should pay more attention on the activities that will improve the ATM services of their banks if they wish to increase the ROA value of their banks as this will lead to high customer's satisfaction and patronage.

2. When planning to improve their ROA value, Management should not just focus on POS transactions but on other activities that would enhance the ROA.

3. Management while considering the enhancement of the ROA should not depend on WEBV though it is important for the general performance of the bank.

4. Though the NIPV has insignificant positive effect on the ROA, the bank needs it to remain competitive

5. Management in attempting to improve the ROA should not base its decision on the NEFTV though it is still necessary for customers' convenience and satisfaction.

\section{REFERENCES}

[1] Abaenewe, Z.C., Ogbulu, O.M. \& Ndugbu, M.O. (2013). Electronic banking and bank performance in Nigeria. West African Journal of Industrial \& Academic Research, 6(1).

[2] Adewoye, J. 0. (2013). Impact of mobile banking on service delivery in the Nigerian commercial banks. International Review of Management and Business Research, 2(2).

[3] Ajayi, L. B. (2014). Effect of cashless monetary policy on Nigerian banking industry: Issues, prospects and challenges. IJBFMR 2, 29-41 ISSN 2053-1842

[4] Ajayi, S. I. \& Ojo, O. O. (2006). Money and banking: Analysis and policy in the Nigerian context. Ibadan Daily Graphics

[5] Ayodele T.D. (2015) Nigerian payment systems through electronic banking: A review. International Journal of Transformations in Business Management,5(5- II).
[6] CBN Presentation July (2012). Towards a cashless Nigeria: Tools and Strategies. NCS24th National Conference

[7] Ewa, K.E \& Inah, E. U. (2016). Evaluating Nigeria cashless policy implementation. International Journal of Business and Social Research, 6(5).

[8] Ezuwore- Obodoekwe C. N., Eyisi A.S, Emengini S.E. \& Alio F. C. (2014). A critical analysis of cashless banking policy in Nigeria. IOSR Journal of Business and Management, 16(5-V), 30-42.

[9] Hassan S.U., Aliyu M. \& Farouk M.A. (2013). Electronic banking products and performance of Nigerian listed deposit money banks. American Journal of Computer Technology and Application, 1(10), 138 - 148. https://www.vanguardngr.com/2017/10/fundtransfer-nip-neft/

[10] Itah A. J. \& Ene E. E. (2014). Impact of cashless banking on banks' profitability: Evidence from Nigeria. Asian Journal of Finance \& Accounting, 6(2).

[11] Kiragu, M. (2017). Effects of e-banking on the financial performance of Kenyan banks (Unpublished).

[12] Mohammad, O.A. \& Saad, A.A. (2011). The impact of ebanking on the performance of Jordanian banks. Journal of Internet Banking and Commerce, 16(2).

[13] Morufu, 0. (2016) E-payments adoption and profitability performance of deposits money banks in Nigeria. IPASJ International Journal of Information Technology, 4(3).

[14] Mugodo, E.A. (2016). Effect of electronic banking on the financial performance of commercial banks in Kenya (Unpublished).

[15] National Bureau of Statistics / Central Bank of Nigeria (CBN)(2017)

[16] Ngango M. A. (2013). Electronic banking and financial performance of commercial banks in Rwanda: A case study of Bank of Kigali (Unpublished)

[17] Njogu, J. N. (2014). The effect of electronic banking on profitability of commercial banks in Kenya (Unpublished).

[18] Obiekwe C.J. \& Anyanwaokoro M. (2017). Electronic payment methods and profitability of banking firms in Nigeria: A panel data analysis. International Journal of Finance and Accounting, 6(3), 67-74.

[19] Odior, E. S. \& Banuso F. B. (2013). Cashless banking In Nigeria: Challenges, benefits and policy implications European Scientific Journal, 8(12).

[20] Ogare, H. O. (2013). The effect of electronic banking on the financial performance of commercial banks in Kenya. (Unpublished)

[21] Okoye, P.V.C. \& Ezejiofor R. (2013). An appraisal of cashless economy policy in development of Nigerian economy. Research Journal of Finance and Accounting, 4(7).

[22] Omotunde M., Sunday T. \& John-Dewole A.T. (2013). Impact of cashless economy in Nigeria. Greener Journal of Internet, Information and Communication Systems, 1 (2), 40-43. 
International Journal of Trend in Scientific Research and Development (IJTSRD) @ www.ijtsrd.com eISSN: 2456-6470

[23] Ordu, M. M. \& Anyanwaokoro, M. (2016). Cashless economic policy in Nigeria: A performance appraisal of the banking industry. IOSR Journal of Business and Management (IOSR-JBM) 18(10-III), 01-17.

[24] Osazevbaru, H. O. \& Yomere, G.O. (2015). Benefits and challenges of Nigeria's cash-less policy. Kuwait Chapter of Arabian Journal of Business and Management Review, 4(9).

[25] Oyewole O.S., Abba M., Gambo E. J. \& Arikpo, I. A. (2013). E-banking and bank performance: evidence from Nigeria. International Journal of Scientific Engineering and Technology, 2(8), 766-771.

[26] Princewell, N. A. (2013). Shifting policy paradigm from cash-based economy to cashless economy: The Nigeria experience. Afro Asian Journal of Social Sciences, Volume 4, No. 4.4 Quarter IV, ISSN: 2229 - 5313

[27] Taiwo, J.N. Ayo, K. O., Afieroho E. O. \& Agwu, M. E. (2016) Appraisal of cashless policy on the Nigerian financial system. West African Journal of Industrial \& Academic Research, 16(1).

[28] Tijani, J. A. \& Ilugbemi, A. O. (2015). Electronic payment channel in the Nigeria banking sector and its impacts on national development. Asian Economic and Financial Review, 5(3), 521-531.

[29] Tunmibi S. and Falayi E. (2013). IT security and ebanking in Nigeria. Greener Journal of Internet, Information \& Communication System 1 (3), 061-065

[30] Umanhonlen, Umanhonlen, and Omoruyi (2015). Appraisal of the Impact of e-banking and cashless society in the Nigerian economy. Management and Economics Research Journal, 1, 34-45

[31] Yaqub J.O., Bello H.T., Adenuga I.A. \& Ogundeji M.O. (2013). The cashless policy in Nigeria: prospects and challenges. International Journal of Humanities and Social Science, 3(3).

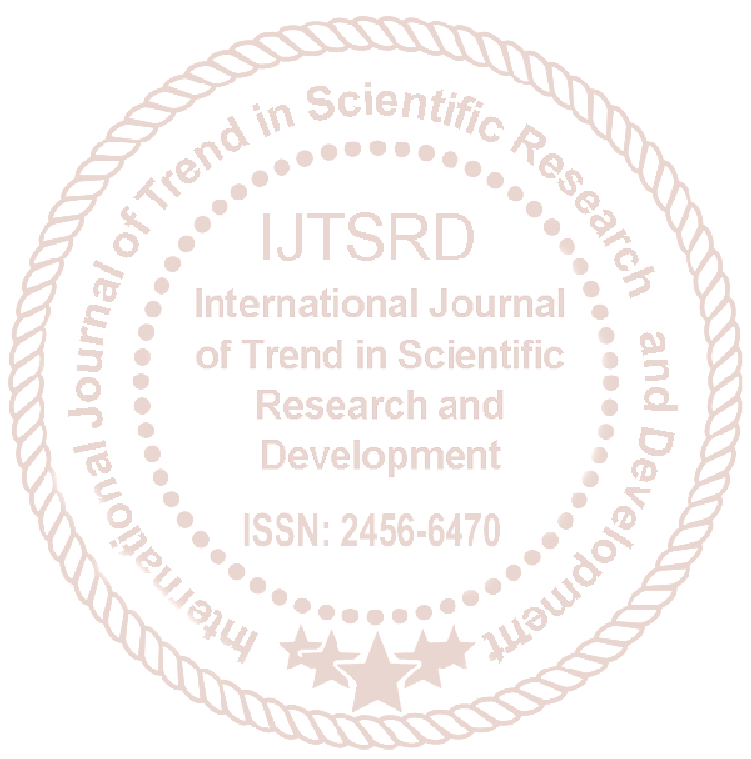

